\title{
Evaluating Non-STEM Students' Understanding of Evolution: Basis for Designing Pedagogical Intervention
}

\author{
Jastine Kent Florungco ${ }^{*}$ * \\ ${ }^{1}$ Centro Escolar University, Philippines \\ ${ }^{2}$ De La Salle- College of St. Benilde, Philippines \\ *e-mail: 1*florungco2001423@ceu.edu.ph
}

\begin{abstract}
Article Information
Received: July 25, 2021

Revised: August 08, 2021

Accepted: October 12, 2021

Online: November 15, 2021
\end{abstract}

\begin{tabular}{l}
\hline \multicolumn{1}{c}{ Keywords } \\
\hline Understanding Evolution, Non- \\
STEM Students', Human Evolution
\end{tabular}

\begin{abstract}
Teaching human evolution should be initialized by understanding the learners' perspective to yield fruitful results. This study was conducted to aid in achieving that objective and provide ways for educators to develop strategies that learners can perceive and appreciate, particularly those who are not inclined toward science. This study also utilized a qualitative research design and descriptive approach to understanding the learners' perspective in Evolutionary concepts. The majority of the respondents are believers in the theory of human evolution. Interviews were conducted to gather data. Most respondents expressed their belief that modern humans are successors of ape-like organisms. The majority of the same informants mentioned their need for clarity about the stages that humans underwent during history, while almost all of those respondents stated the utilization of various graphic materials to elucidate these evolutionary concepts. It was recommended that educators engage in learning methods that call the attention and those that the students can easily understand.
\end{abstract}

\section{INTRODUCTION}

As a field of study, the theory of human evolution has been deemed important but not given too much focus throughout the secondary high school curriculum. However, this body of knowledge not only tackles the systems and processes that are occurring on humans and their nature, but it also enlightens us about the origins of every species occurring on this planet; hence, the study of evolution was proven to be a necessity in this field.

A publication by the National Academies of Sciences (1998) mentioned that knowing the evolutionary ideas can aid in solving questions that surround the relationship of every living species in our world today. Having to accept this study may lead to further understanding of one's origin or the changes that occurred from millions of years ago up to the present. That is easier said than done. A study published by Hermann (2011) revealed that American students do not necessarily agree on the aspects being taught in their evolution class, which leads to low exam scores on the said subject matter. Part of this unacceptance is the western view that a higher divine being made all. Short and Hawley (2015) noted that Americans' resistance in accepting the evolutionary theory is due to their belief in the opposing creationist view, stating that everything is made by God, as mentioned in the Holy scriptures. It is supported by a study by Clores and Limjap (2006), in which it was revealed that students' lack of understanding in evolutionary concepts was either due to their theological beliefs or their inability to have further encounters on the said subject matter. It can be connected to the findings of Cotner, Thompson, and Wright (2017), discussing on their study that NON-STEM learners are tend to have a 
more flourished interest on arts and religion than Science. This is in contrast as to what Nelson Laird et. Al. (2011) found, that instructors in NON-STEM programs implement a more focused typed of teaching methods in discussing science concepts more than those who handle STEM courses. In addition, Plutzer, Branch, and Reid (2020) pitched that there are inconsistencies on the part of most of the teachers who, as the study implied, are either avoiding to discuss the concepts of evolution, or provide contradicting ideas that can lead to confusion on the learners' part.

This study aims to understand better how Senior High School students who do not specialize in science view human biology and evolution. Specifically, this study aims to identify students' ideas about human evolution. In addition, this also aims to devise a plan that will help elaborate certain evolutionary concepts. Lastly, This study provided alternative motivational and instructional techniques to teachers of NON-STEM (Science, Technology, Engineering, and Mathematics) students in learning these evolutionary or biological concepts.

\section{LITERATURE REVIEW}

This study aims to provide a necessary understanding of how students from other fields view biological and evolutionary concepts and their importance. As mentioned in a work of the University of California-Berkeley, having the necessary knowledge about the origin of every species might help discover the vital solution to the world's problem.

\section{On non-STEM students' perspective on Human Evolution}

Science subjects are vital in the Philippine education system since they are incorporated in the Basic education curriculum from elementary to senior high school. Still, several problems need to be resolved for science education to be taught properly. Cotner, Thompson, and Wright (2017) exclaimed that those students from other fields view that science is not interrelated to other fields of study. Monton (2008) highlighted that several high school students have difficulty utilizing laboratory equipment, aside from the fact that it is not easy for these learners to comprehend instructions in English. Moreover, some of them simply do not grasp the importance of studying these concepts in their daily lives. It is further supported by Cotner, Thompson, and Wright's (2017) research, saying that non-STEM students are most likely to display inaccurate information about scientific concepts. Another study, this time by Rogayan and Albino (2019), noted that students from the Philippines have a common misconception in certain topics, particularly in genetics and zoology. A study by Nieberding, Buxner, Elfring, and Imprey (2021) revealed that non-Science students' scores on a given assessment about biological concepts were lower than those of STEM majors. Subsequently, some biological ideas are not accurately expressed by STEM and Non-STEM students. On the other hand, a study conducted by Seoh, Subramaniam, and Hoh (2013) showed that there are still a significant number of Singaporean students who have doubts in believing that evolution took place. It is mentioned that evidence from fossils is not sufficient for these students to say there was an evolution.

Another point of view about students' learning of Biology and evolution is their religious beliefs. Cotner, Brooks, and Moore (2010) took notice of the convenience of teaching the biblical origins of life in schools compared to the ideas being pushed by scientists. Clores and Limjap's (2006) study indicated that the learners' scientific understanding is greatly influenced by their perspectives based on politics and religion. This claim is supported by a published material of Cotner et al. Moore (2010), stating that the faith and theological views of the learners greatly affect their way of accepting and understanding the concepts of the theory of evolution and Biology. Rissler, Duncan, and Caruso (2014) mentioned that those students who do not identify themselves as religious are the only ones who showed improvements in the understanding and acceptance of human evolution thru the assessment they have taken. Aside from that, the same paper revealed that the families and educational institutions; these students belonged to are somewhat influencing them in perceiving the ideas brought about by the study of the origins of life.

Furthermore, learners who identified themselves as liberals tend to agree more on evolution while also considering the creationist view. On the contrary, Bertka, Pobiner, Beardsley, and Watson (2019) showed that though there are learners who have doubts about the evolutionary concepts, they are willing to listen to the concepts for them to be able to discuss the different points of view on this subject. On the contrary, this study also mentioned that few students did not welcome the idea of 
discussing theological beliefs in a Science class. Knowing that Laats and Siegel (2016) mentioned that every learner's difference in beliefs and traditions should never hinder studying evolution and other scientific concepts. According to the article, understanding the basic principles of the theories about the origin of life here on Earth can play a key role in answering questions that surround the other aspects of biology. To add, the same article cited a study conducted in the state of Arizona, claiming that it is possible to learn the basic ideas of evolution without changing their beliefs about the theological explanation they believe in.

On the other hand, it has been mentioned that those who believe in the biblical aspect can object if an idea is forced into them. Ideas that are not aligned with the principles of their faith. Rissler et al. had similar points of view, indicating that understanding the concepts of human evolution taught in science classes does not guarantee these learners' acceptance. Other aspects of why students often cast off the natural part of human evolution are the influence of media outlets, such as television and conspiracies found on the internet.

\section{Methods used in teaching concepts in Human Evolution}

Institutions from all over the world utilized varying techniques deemed effective in teaching biological and evolutionary concepts. Џin and Bierma (2013) study revealed that employing a guided learning approach in teaching science in a big class is beneficial. As the results revealed, the implemented assessment methods showed consistent improvements in understanding scientific concepts attributed to these teaching techniques.

Another way to identify the proper teaching strategy in lecturing about evolution is to identify the challenges that come along with it. Pobiner (2016) identified the mistrust and refusal of students to learn these ideas and their capabilities to understand the concepts and terminologies it contains and their religious beliefs. According to him, educators handling these subjects must be well-equipped with the skills and materials to properly deliver these lessons and address these obstacles. To address these potential hindrances, Pobiner added that teachers must first have some sort of pre-test to clarify concepts that need to be elaborated on and understand the students' views about the origins of life. It is to supplement the findings of Galli and Meinardi (2011) to know and recognize the learners' ideas and build away from that to combat misconceptions. Rogayan and Albino (2019) shared the same thoughts, mentioning that starting before the lecture is proper to measure learners' knowledge about science. Since the teachers' roles are key in enlightening these learners' minds, they must employ various techniques to convey these lessons properly. Short and Hawley (2015) indicating the positive results of employing an active class discussion, such as having group activities and working with pairs, to understand these theories. In addition, incorporating other scientific concepts, psychology in particular, also aid in acquiring necessary concepts of evolution. This view is effective since students can relate to topics they experience in real life, such as having friends and their views about love and family.

Religious beliefs and concepts are a major difficulty in teaching evolution since this is commonly in contrast to what the students perceive to know or accept (Hermann, 2012). Hermann noted that learners tend to have difficulty rationalizing scientific and religious concepts, which leads to misunderstandings about world views. Respondents to this study mentioned that there should be a line to which ideas can be understood but may not be believed in. In addition, a respondent considered that comparing what science says and what the bible says can play an integral role in distinguishing ideas and for students to retain concepts about the matter. Bertka et al. noted that having a harmonious class discussion can positively affect making students understand evolution perceptions. In addition, Rogayan and Albino included that a remedial session might be necessary to supplement what has been taught in the classroom. Moreover, Hermann (2011) cited a 2006 work Harris, claiming that children develop their understanding of knowledge with the things being exclaimed by their parents. It is one of the seen importance of elementary and high school teachers' roles in correcting the misconceptions brought about by the groups of people in the learners' environment.

The National Academies of Sciences (1998) integrated a series of steps to introduce evolutionary concepts to students. First, teachers must introduce the concepts gradually to activate students' curiosity and get their attention. It is also a way to let the learners figure out the problem at hand. After the successful introduction of the topic, teachers should slowly integrate the contents of the material into a discussion and provide additional resources for the students' perusal. On the other hand, 
Hermann (2011) suggested that curriculum developers and implementers should formulate a curriculum that suits the needs of learners' understanding about evolution. It includes incorporating subjects as early as the elementary level since it was deemed that the perceptions and ideas of learners are formed and influenced even before high school years are attained. The same study reiterated that teachers must emphasize, distinguish and explain to these pupils the differences of knowing and believing. The perceptions of these two factions must be established as early as possible to avoid the conflicts above in the cognitive understanding of evolution. Shenk (2000) added that teaching the scientific concepts of human evolution should be divided and taught sparingly based on the age and grade levels of the students, aiming to identify the topics that shall serve as the building blocks of learning for these subjects.

\section{METHODS}

This study utilized qualitative design, specifically a descriptive approach in gathering and presenting the data. Silverman (1997) indicated that qualitative research is used to understand the perceptions and experiences of certain groups of people. Nassaji (2015) mentioned that the descriptive design further elaborates on how and why certain situations exist. This method was employed to have a clear and direct statement that can serve as basis on how the non-Science students perceive or understand the concepts and theories about human evelotion.

There were 30 respondents considered in this study, all of which are graduates of Senior High School from batch 2021. The respondents came from Accountancy and Business Management, Humanities, Social Sciences Strand, and Technical-Vocational Track. The respondents are graduates of a private school in Caloocan City. All respondents have taken Earth and Life Science courses in Senior High School.The respondents were selected thru convenience sampling. The sampling method was employed since the data collection procedures were conducted during the summer vacation amid the pandemic, so the number of respondents and the resources to gather data are very limited. In addition, since this study is qualitative, fewer respondents are advisable. The data were collected through interviews conducted via google meet. Students who declined to be interviewed online were given a chance to answer the questions via google forms. The data collection process started on July 3, 2021, and ended on July 13,2021. After the time frame, the data gathered were analyzed via thematic analysis.

The researchers adhere to the ethics that should be observed in research. The elicited responses will be used solely for this study; hence, confidentiality will be observed and practiced. In addition, the profile of the respondents shall remain anonymous. The respondents were informed of their right to withdraw from this study whenever they wished to do so. This study intended no harm for the participants, and due to the ongoing pandemic, health and safety protocols were observed and followed in the duration of this study.

\section{RESULTS}

This part of the study shows the data gathered by the researcher. The data gathered were organized, presented, analyzed, and interpreted by the researcher to formulate a well-thought conclusion.

\section{Profile of respondents according to their strand}

The first part of this study shows the profile of the respondents based on the strand that they graduated in their Senior High School. For example, it was known that sixty percent of the respondents were graduates of the Humanities and Social Sciences strand, while twenty-seven percent were from the Accountancy and Business Management strand. The remaining thirteen percent of the respondents were graduates from the Technical-Vocational track. At the start of this study, respondents will come from Senior High School Batch 2021 that took strands unrelated to Science, Technology, Engineering, and Mathematics (STEM).

\section{Perception of students about evolution}

The next part aimed to determine the respondents' perception of human evolution initially. Ninety percent of the respondents stated that they are considered believers of the theory of evolution, whereas only ten percent exclaimed that they do not believe in such an idea. Furthermore, all of these 
respondents underwent Earth and Life science courses incorporated into the Senior High School curriculum and understood basic scientific concepts. The result implies that most of these respondents exhibited open-mindedness in the subject matter and showed interest in studying the topics above.

Bertka et al. (2019) mentioned that it is a key step in studying evolution to know the learners' perceptions about the topic and ensure that their needs in the discussion will be catered to.

\section{Respondents' understanding of Human Evolution}

Upon the analysis of the data gathered, it appeared that forty percent of the respondents had the notion that modern humans are descendants of species that are ape-like or those who came from apes, with respondent two saying that "Science teachers taught us that we came from the specie of Monkeys and Orangutan." Another answer worth noting, this time by respondent 6, explained that he "does not know much about the real or scientific explanation of Human Evolution," adding that he "just know that Human Evolution says that individuals originated from ape-like ancestors." Also expressing that "This implies that most of the students had the foundation of their knowledge are based on what these respondents have learned in the school, on the lectures given by their teachers, or by what they have already read or seen in various sources.

Hermann (2011) acknowledged that learners nowadays have little knowledge about human evolution, primarily because these topics are only tackled slightly during secondary biology.

\section{Evolutionary aspects that the respondents need clarity}

This juncture of the study focuses on the part of human evolution that need surther clarification to be understood by the students. It was revealed that students are adamant about gathering additional knowledge about the stages of human evolution. Particularly, these respondents want to know the basics of this theory, with respondents asking about "How the people who studied about human evolution concludes that the first humans were ape-like beings." To add, respondent two also shared the same sentiment, saying that he "do not completely understand the timeline or the stages of human evolution" and noted that he "has a little knowledge about it, so I want to study it further." On the other hand, a question was raised by respondent 29, asking, "why don't we have any records from the past centuries about developing organs other organisms have, gills for example, throughout the time since, we, humans adapt to its environment particularly"? Meanwhile, respondent 6 declared that he needs clarity of most ideas about evolution. It implies that these learners' understanding has been limited since several ideas are unclear.

Bishop and Anderson (1990) found out that not science majors' learners knew evolution as a slow change that happened slowly.

\section{Students' perception of how teachers should teach human evolution}

The final part of the study aims to address the students' ideas about how they would completely understand the concept of human evolution. It was asked how educators would explain these ideas to them, and forty-three percent of the respondents agreed that it is of great help if the teachers utilize different types of graphic aids in explaining and teaching human evolution. Respondent 7 explained that visual aids would make the concepts "easier to remember." In addition, respondent 2 pointed out that using pictures and videos "gives us students a better representation of what Human Evolution truly is." Respondent 15, on the other hand, suggested that the materials to be used must contain only the important information, considering that it should be more interesting and clearer. Furthermore, it implies that learners' attention will be fully attained if the materials on this topic contain depictions that can be perceived directly by them.

Bertka et al. (2019) suggested that having an active learning strategy will significantly improve learners' understanding of human evolution. However, it also involves addressing misconceptions and getting out of the usual teacher-centered method.

\section{CONCLUSION}

This study was conducted to know the ideas and perceptions of non-STEM students regarding the theory and human evolution, which can serve as a basis in identifying the concepts that need clarifications and help the educators develop a successful classroom discussion. It was revealed that 
most of the respondents of this study are senior high school graduates who took Humanities and Social Science as their focus strand. The majority of the respondents mentioned that they tend to believe in the theory of human evolution. These learners were requested to share their understanding of these topics, and it was noted that most of these respondents had the idea that modern humans came from ape-like ancestors. One of the reasons given by the respondents for these beliefs is due to the teachings they got from their lower years in school. The same set of respondents was also asked the concepts needing clarification. The majority of the responses were geared in saying that the learners would appreciate it if explanations were directed towards events surrounding the stages of human evolution. Most learners expressed confusion about these aspects, stemming from the limited time allotted for these courses. Lastly, the respondents were given a chance to state how they deemed to learn the theory of evolution more comprehensively, and most of them exclaimed that it would be productive if the instructors would use materials that will include good photographs and video presentations that can easily be perceived.

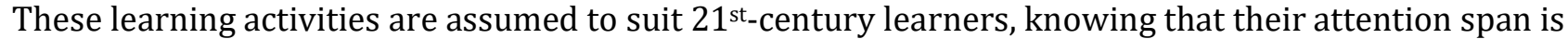
shorter, and they can be easily distracted by certain things.

\section{Recommendations}

Based on the finding of this study, the following recommendations were formulated:

1. For the educators, to utilize materials that suit the needs of the current learners. Those who are not inclined to study science understandably have little to no knowledge about such topics, but this study revealed that these students are willing to learn. Having the right method and materials will address the problems faced in class.

2. For the students to continuously read about the human evolution in textbooks and resources that can be found online. It will aid in developing a deeper understanding of the matter.

3. Future researchers emphasize revisiting teachers' understanding of these topics and delivering these concepts in a classroom set-up. It is a key component of having the learners grasp these courses.

\section{REFERENCES}

Berkman, M. \& Plutzer, E. (2012). An evolving controversy: The struggle to teach Science in Science class. American Educator. https://www.aft.org/sites/default/files/periodicals/berkman plutzer.pdf

Bishop, B.A. \& Anderson, C.W. (1990). Student conceptions of natural selection and its role in evolution. Journal of Research in Science Teaching 27(5). https://doi.org/10.1002/tea.3660270503

Clores, M.A. \& Limjap, A.A. (2006). Diversity of Students' Beliefs about Biological Evolution. Asia Pacific Journal of Education 26(1). https://eric.ed.gov/?id=E]830125

Nieberding, M., Buxner, S., Elfring, L., \& Imprey, C. (2021). Undergraduate Student Conceptions of DNA and Their Understanding of Basic Science. Journal of College Science Teaching, 50(5). https://www.nsta.org/journal-college-science-teaching/journal-college-science-teachingmayjune-2021/undergraduate-0

Plutzer, E., Branch, G., \& Reid A. (2020). Teaching evolution in U.S. public schools: a continuing challenge. Evolution: Education and Outreach 13(14). https://doi.org/10.1186/s12052-020-00126-8

Jin, G. \& Bierma, T. (2013). STEM for non-STEM Majors: Enhancing Science Literacy in Large Classes. Journal of College Science Teaching, 42(6). https://www.jstor.org/stable/43632151?fbclid=IwAR2GUtrfNGXXZkGvf5TPkOsAfxIKpHvK1mO RznxkxePE 1-3XL7doXS2k

Laats, A. \& Siegel H. (2016, April 19). Teaching evolution Isn't About Changing Beliefs. EducationWeek. https://www.edweek.org/policy-politics/opinion-teaching-evolution-isnt-about-changingbeliefs/2016/04

Nelson Laird, T.F., McCormick, A.C., Sullivan, D.F., \& Zimmerman, C. (2011). STEM/Non-STEM Differences in Engagement at US Institutions. Peer Review 13(3). 
Copyright (C) Jastine Kent Florungco, et al.

INTERNATIONAL JOURNAL OF ASIAN EDUCATION, Vol. 2, No. 4, December 2021

https://www.aacu.org/publications-research/periodicals/stemnon-stem-differences-engagementus-institutions?fbclid=IwAR3aCWzFZle5Db s7c8hV4IhV4wTjJF2s5ExPYwe5NzO GpMwUzwgw5mio

Bertka, C.M., Pobiner, B., Beardsley, P., \& Watson, W.A. (2019). Acknowledging students' concerns about evolution: a proactive teaching strategy. Evolution: Education and Outreach 12(3). https://evolution-outreach.biomedcentral.com/articles/10.1186/s12052-019-00950?fbclid=IwAR3NhU5g4Petiv1f6PKo64jQKOoceWBOruf-wZOpxEwPXGrb7Ys8av720CoS

Cotner, S., Thompson, S., \& Wright, R. (2017). Diversity of Students' Beliefs: Do Biology Majors Really Differ from Non-STEM Majors about Biological Evolution. CBE-Life Sciences Education. 16(3). https://doi.org/10.1187/cbe.16-11-0329

Cotner, S., Brooks, D.C., \& Moore, R. (2010). Is the age of the Earth one of our "sorest troubles?" Students' perceptions about deep time affect their acceptance of evolutionary theory. Evolution 64(3). https://doi.org/10.1111/j.1558-5646.2009.00911.x

Seoh, K.H.R., Subramaniam, R., \& Hoh,Y.K. (2013). High school students' understanding of evolution. Australian Association for Research in Education. https://files.eric.ed.gov/fulltext/ED603253.pdf

Galli, L.M.G. \& Meinardi E.N. (2011). The Role of Teleological Thinking in Learning the Darwinian Model of Evolution. Evolution: Education and Outreach 4. https://doi.org/10.1007/s12052-010$\underline{0272-7}$

Hermann R.S. (2011). Breaking the Cycle of Continued Evolution Education Controversy: On the Need to Strengthen Elementary Level Teaching of Evolution. Evolution: Education and Outreach 4. https://doi.org/10.1007/s12052-011-0325-6

Hermann R.S. (2012). Cognitive Apartheid: On the Manner in Which High School Students Understand Evolution without Believing in Evolution. Evolution: Education and Outreach 5. https://doi.org/10.1007/s12052-012-0446-6

Nassaji, H. (2015). Qualitative and descriptive research: Data type versus data analysis. Language Teaching Research 19(2). https://doi.org/10.1177/1362168815572747

National Academy of Sciences (1998). Teaching About Evolution and the Nature of Science. https://www.nap.edu/read/5787/chapter/7

Pobiner, B. (2016). Accepting, understanding, teaching, and learning (human) evolution: Obstacles and opportunities. American Journal of Physical Anthropology 159(61). https://doi.org/10.1002/ajpa.22910

Rissler, L.J., Duncan, S.I., \& Caruso, N.M. (2014). The relative importance of religion and education on university students' views of evolution in the Deep South and state science standards across the United States. Evolution: Education and Outreach 7. https://doi.org/10.1186/s12052-014-0024-1

Rogayan Jr, D., Albino, M.M. (2019) Filipino Students' Common Misconceptions in Biology: Input for Remedial Teaching. Online Science Education Journal 4(2).

https://www.researchgate.net/publication/337683279 Filipino Students' Common Misconceptions in Biology Input for Remedial Teaching

Silverman, D (1997). Qualitative Research. Sage Publishing. Retrieved from https://books.google.com.ph/books?hl=en\&lr=\&id=7RwJEAAAQBAJ\&oi=fnd\&pg=PP1\&dq=qualit ative+research\&ots=LXi0GXOYZv\&sig=gUxktCmPPCS9htPapF sPgXNR1I\&redir esc=y\#v=onepage \&q=qualitative $\% 20$ research \&f=false

Shenk, J.D. (2000). Evolutionism and Creationism in Schools Today. https://www.goshen.edu/bio/Biol410/bsspapers00/jillds.html?fbclid=IwAR3rAxarWgDxQMrbIz EQwowKoe6evQ06NkQfbc goxsjlcxQb3f0gypz5Ec

Short, S.D. \& Hawley, P.H. (2015). The Effects of Evolution Education: Examining Attitudes toward and Knowledge of Evolution in College Courses. Evolutionary Psychology 13(1). https://doi.org/10.1177\%2F147470491501300105 
Ziegler, B. \& Montplaisir, L. (2014). Student Perceived and Determined Knowledge of Biology Concepts in an Upper-Level Biology Course. CBE Life Sciences Education 13(2).

https://dx.doi.org/10.1187\%2Fcbe.13-09-0175 